\title{
PENGARUH RETURN ON ASSET DAN NET PROFIT MARGIN TERHADAP HARGA SAHAM PERUSAHAAN PADA SUB SEKTOR HOTEL, RESTORAN, DAN PARIWISATA YANG TERDAFTAR DI BEI
}

\author{
${ }^{1}$ Jaka Maulana, ${ }^{2}$ Darul Difo Utama \\ Program Studi D4 Akuntansi Keuangan \\ Politeknik Pos Indonesia \\ jakamaulana@poltekpos.ac.id
}

\section{ABSTRAK}

Keindahan alam Indonesia, menjadikan perhotelan sebagai salah satu bisnis yang menjamur di Indonesia. Persaingan yang ketat menyebabkan hotel membutuhkan modal untuk bersaing, salah satunya dengan cara menjual saham di Bursa Efek Indonesia. Laporan ini bertujuan untuk mengetahui apakah variabel Return On Asset dan Net Profit Margin mempunyai pengaruh terhadap harga saham perusahaan sub sektor hotel, restoran, dan pariwisata yang tercatat di BEI. Dalam penelitian ini menggunakan metode kuantitatif dengan menggunakan laporan keuangan perusahaan sub sektor hotel, restoran, dan pariwisata yang tercatat di BEI sebagai populasi. Pengambilan sampel menggunakan teknik purposive sampling sehingga mendapatkan sampel sebanyak 40 laporan keuangan. Alat analisis yang digunakan dalam penelitian ini adalah uji normalitas, korelasi product moment, korelasi ganda, regresi ganda, koefisien determinasi, uji t, dan uji f. Hasil dari penelitian mendapatkan bahwa variabel Return On Asset dan Net Profit Margin tidak berpengaruh terhadap harga saham perusahaan sub sektor hotel, restoran, dan pariwisata yang tercatat di BEI baik secara parsial maupun simultan.

Kata Kunci : Return On Asset, Net Profit Margin, Harga Saham

\section{ABSTRACT}

The beauty of indonesian's nature makes hotel become one of popular bussiness in Indonesia.. The strict competition makes this bussiness need more capital to competete which can be getted with selling stock paper in Indonesian Stock Exchange. This paper has purpose to know if Return On Asset and Net Profit Margin have influence to stock price of sub sectors hotel, restaurant, and tourism's companies that listed in Indonesian Stock Exchange. This paper use financial statement of sub sectors hotel, restaurant, and tourism's companies as population. The sampling method use purposive sampling with resulting about 40 sample of financial statement. Analizing tools that used are normality test, product moment correlation, multiple correlation, multiple regression, koefisien determination, t-test, and f-test. The result from this research is Return On Asset and Net Profit Margin don't have influence to stock price of sub sectors hotel, restaurant, and tourism's companies that listed in Indonesian stock exchange, partially and simultan.

Keyword :Return On Asset, Net Profit Margin, Stock Price

\section{Pendahuluan}

Bidang pariwisata merupakan bidang dengan potensi bisnis yang terbilang besar di Indonesia. Hal ini terjadi dikarenakan Indonesia terkenal dengan budayanya yang beragam serta alamnya yang indah sehingga sangatlah menarik bagi wisatawan baik dalam negeri walaupun luar negeri. Banyaknya wisatawan yang datang untuk menikmati keindahan alam di daerah wisata, menyebabkan dibutuhkanlah tempat penginapan. Oleh sebab itulah bisnis penginapan seperti perhotelan menjadi salah satu bisnis yang menarik dan berpotensi tinggi untuk dijalani.

Diambil menurut kumparan.com, "Kepala BPS Suhariyanto... turunnya jumlah kunjungan wisman, salah satunya disebabkan oleh erupsi Gunung Agung di Kabupaten Karangasem, Bali... sepanjang Mei tingkat okupansi hotel hanya 53,86\% atau turun 2,21 
poin dibandingkan dengan periode yang sama tahun lalu yang tercatat sebesar 56,07\%. Begitu juga jika dibandingkan dengan periode April 2018 yang mengalami penurunan sebesar 3,57 poin."(Nurhayat, 2018)

Bisnis perhotelan sangatlah bergantung dengan jumlah wisatawan yang datang ke daerah wisata. Akibatnya, persaingan yang terjadi antar hotel menjadi sangat kuat sehingga suatu hotel memerlukan pelayanan yang lebih baik dari pesaingnya dalam upaya menarik wisatawan. Setiap hotel dipaksa untuk bekerja lebih keras untuk selalu berusaha untuk berkembang dan mencari terobosan baru yang unik.

Untuk merealisasikannya, perusahaan membutuhkan modal yang besar. Dengan menjadi perusahaan Go Public yang tercatat di Bursa Efek Indonesia, pihak perusahaan memiliki hak untuk dapat menjual sahamnya kepada masyarakat yang merupakan calon investor untuk mendapatkan modal dalam upaya tetap eksis di persaingan bisnis Indonesia.

Saham merupakan suatu bukti yang dikeluarkan oleh perusahaan bahwa investor yang memegang saham tersebut memiliki hak atas laba yang dimiliki oleh perusahaan. Mengingat penanam saham mendapatkan keuntungannya melalui dividen, maka diperlukan analisis yang menggunakan laba bersih. Oleh sebab itu, Return On Asset (ROA) dan Net Profit Margin (NPM) dapat digunakan menjadi alat analisis dalam mengetahui apakah saham suatu perusahaan layak untuk dibeli atau tidak.

Return On Asset (ROA) memperbandingkan tingkat pengembalian laba bersih dari perusahaan atas aset yang dipunyai, dimana aset yang dimiliki ini dapat berupa kamar, tempat rekreasi dan lain-lain. Dengan semakin menurunnya tingkat okupansi, berarti ada kamar atau aset yang berlebih yang tidak digunakan. Oleh sebab itu dari sisi perusahaan lebih baik untuk berkreatifitas untuk mencari cara agar kamar dapat dipenuhi.

Net Profit Margin (NPM) memperbandingkan laba bersih yang dimiliki perusahaan dan pendapatan yang dihasilkan oleh perusahaan. Dimana pendapatan tidak hanya berupa laba, namun juga biaya yang dikeluarkan oleh perusahaan. Memaksimalkan laba dan mengurangi biaya sekecil-kecilnya merupakan kunci agar pihak perusahaan mendapatkan laba yang besar.

\section{Tabel 1}

Harga Saham Per Lembar Usaha Perhotelan Tercatat BEI (dalam Rp)

\begin{tabular}{|c|c|c|c|c|c|}
\hline Kode Perusahaan & $\begin{array}{c}\text { Tahun } \\
\mathbf{2 0 1 5}\end{array}$ & $\begin{array}{c}\text { Tahun } \\
\mathbf{2 0 1 6}\end{array}$ & $\begin{array}{c}\text { Tahun } \\
\mathbf{2 0 1 7}\end{array}$ & $\begin{array}{c}\text { Tahun } \\
\mathbf{2 0 1 8}\end{array}$ & $\begin{array}{c}\text { Tahun } \\
\mathbf{2 0 1 9}\end{array}$ \\
\hline BUVA & 595 & 570 & 520 & 206 & 74 \\
\hline HOTL & 133 & 127 & 95 & 102 & 156 \\
\hline INPP & 358 & 565 & 650 & 700 & 840 \\
\hline KPIG & 1410 & 1500 & 1275 & 139 & 136 \\
\hline PGLI & 69 & 57 & 155 & 278 & 326 \\
\hline PNSE & 409 & 900 & 1250 & 660 & 332 \\
\hline PSKT & 895 & 735 & 50 & 50 & 50 \\
\hline SHID & 545 & 895 & 1550 & 4300 & 3450 \\
\hline
\end{tabular}

Sumber : www.idx.co.id, data diolah penulis (2020)

Berdasarkan latar belakang dan tabel saham di atas, dapat telihat bahwa harga saham setiap perusahaan sangat berbeda. Setiap tahunnya juga terjadi kenaikan dan penurunan harga saham. Perbedaan ini terjadi akibat perbedaan dalam kemampuan perusahaan dalam memaksimalkan pendapatan dan mengurangi beban sehingga laba yang didapatkan maksimal. 


\section{Identifikasi Masalah}

Berdasarkan latar belakang penelitian di atas dan terdapatnya dua hasil yang berbeda pada penelitian terdahulu, maka saya tertarik untuk melakukan penelitian untuk mengetahui bagaimana pengaruh yang diberikan oleh Return On AssetI (ROA) dan Net Profit Margin (NPM) terhadap harga saham pada perusahaan sub sektor hotel, restoran, dan pariwisata yang terdaftar di Bursa Efek Indonesia baik secara parsial maupun simultan.

\section{Kajian Pustaka \\ Return On Asset}

ROA adalah dari rasio profitabilitas. Menurut Hery dalam Egam, "Return on Asset (ROA) adalah rasio yang menunjukkan seberapa besar kontribusi aset dalam menciptakan laba bersih.”(Egam et al., 2017)

$$
\text { Return On Asset }=\frac{\text { Earning After Tax (EAT) }}{\text { Total Assets }} \times 100 \%
$$

Gambar 1. Rumus Return On Asset 2017)

Indikator dari Return On Asset yaitu Earning After Tax dan Total Asset.(Egam et al.,

\section{Net Profit Margin}

NPM merupakan rasio profitabilitas. Menurut Hery dalam Egam, "rasio Net Profit Margin dihitung dengan membagi laba bersih terhadap penjualan bersih."(Egam et al., 2017)

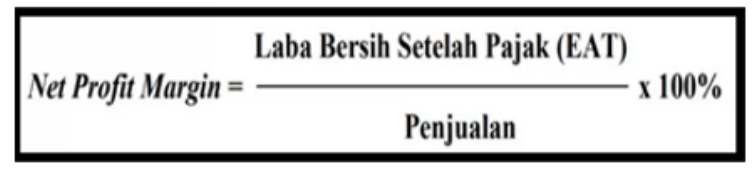

\section{Gambar 2. Rumus Net Profit Margin}

Indikator dari Net Profit Margin yaitu Laba Bersih Setelah Pajak dan Penjualan. (Egam et al., 2017)

\section{Saham}

Menurut Salim dalam Saputra, "saham adalah capital gain yaitu keuntungan yang didapatkan oleh investor dari selisih perbedaan harga pada saat pembelian saham dengan harga pada saat penjualan saham.'(Saputra et al., 2019)

\section{Harga Saham}

Menurut Darmadji dan Fakhruddin dalam Ulfah, "harga saham adalah harga yang terjadi di lantai bursa pada waktu tertentu, harga saham dapat berubah naik atau turun dalam hitungan waktu yang begitu cepat, baik dalam hitungan menit maupun hitungan detik."(Ulfah et al., 2018)

Menurut Darmadji \& Fakhruddin dalam Samosir, "indikator harga saham adalah close atau closing price menunjukkan harga penutupan saham.'(Samosir et al., 2019)

\section{Metodologi Penelitian Jenis Penelitian}

Dalam penelitian ini, metode yang digunakan adalah metode kuantitatif asosiatif. "Metode kuantitatif dapat diartikan sebagai metode penelitian yang berlandaskan pada filsafat positivisme, digunakan untuk meneliti pada populasi atau sampel tertentu, pengumpulan data menggunakan instrument penelitian, analisis data 
bersifat kuantitatif/statistik dengan tujuan untuk menguji hipotesis yang telah diterapkan."(Sugiyono, 2017)

"Judul asosiatif adalah judul penelitian yang bermaksud menggambarkan dan menguji hipotesis hubungan dua variabel atau lebih.”(Sugiyono, 2017)

\section{Teknik Pengumpulan Data}

Sumber data yang dipakai dipenelitian ini merupakan data sekunder. Sumber data yang dipakai yaitu data sekunder yang berasal dari laporan keuangan pada perusahaan sub hotel, restoran, dan pariwisata Go Public yang dapat ditemukan pada Indonesia Stock Exchange(IDX).

Teknik pengumpulan data yang pakai dalam penelitian yang dilakukan yaitu studi kepustakaan dan studi dokumentasi. Studi kepustakaan yaitu mempelajari referensi seperti buku dan jurnal untuk mendukung hipotesis yang dikeluarkan secara teori. Studi dokumentasi dengan mengumpulkan dokumen yang berhubungan dengan permasalahan yang diteliti yang berupa data sekunder atas laporan keuangan perusahaan sub hotel, restoran dan pariwisata yang tercatat di BEI.

\section{Populasi}

"Populasi adalah wilayah generalisasi yang terdiri atas: obyek/subyek yang mempunyai kuantitats dan karakteristik tertentu yang ditetapkan oleh peneliti untuk dipelajari dan kemudian ditarik kesimpulannya.”(Sugiyono, 2017)

Populasi diteliti pada penelitian yang dilakukan adalah laporan keuangan dari perusahaan sub sektor hotel, restoran, dan pariwisata tercatat dalam Bursa Efek Indonesia dari awal tahun mengeluarkan IPO sampai dengan tahun 2019.

\section{Sampel}

"Sampel adalah bagian dari jumlah dan karakteristik yang dimiliki oleh populasi tersebut."(Sugiyono, 2017)

Teknik sampling yang dipakai dipenelitian yang dilakukan yaitu purposive sampling dengan menggunakan kriteria seperti berikut:

\section{Tabel 2}

Kriteria Purposive Sampling

\begin{tabular}{|l|l|c|}
\hline No & \multicolumn{1}{|c|}{ Kriteria } & Perusahaan \\
\hline 1 & $\begin{array}{l}\text { Perusahaan sub sektor hotel, restoran, dan pariwisata yang tercatat } \\
\text { dalam Bursa Efek Indonesia dari awal tahun mengeluarkan IPO sampai } \\
\text { dengan tahun 2019 }\end{array}$ & 34 \\
\hline 2 & Perusahaan berbisnis hotel. & $(22)$ \\
\hline 3 & Perusahaan dengan awal keluar IPO lebih dari 5 tahun. & $(3)$ \\
\hline 4 & Perusahaan yang tidak ditangguhkan dari Bursa Efek Indonesia. & 8 \\
\hline Total & & $5 \times 8=40$ \\
\hline Laporan keuangan 5 tahun terakhir & 1 . \\
\hline
\end{tabular}

Sumber: www.idx.co.id, www.sahamok.com, data diolah penulis (2020)

Berdasarkan tabel diatas dimana dilakukan penyaringan menggunakan purposive sampling didapatkan total laporan keuangan terkumpul sebagai sampel sebanyak 40 laporan.

\section{Teknik Analisis Data}




\section{Uji Normalitas}

"Uji normalitas yang dilakukan dalam setiap penelitian bertujuan untuk menguji apakah dalam model regresi nilai residual variabel-variabel penelitian memiliki distribusi yang normal.'(Zulkifli Hasibuan, 2018)

\section{Korelasi Product Moment}

"Korelasi product moment digunakan untuk menguji hipotesis hubungan antara satu variabel independen dengan satu dependen."(Sugiyono, 2017)

\section{Korelasi Ganda}

"Korelasi Ganda digunakan untuk menguji hipotesis tentang hubungan dua variabel independen atau lebih secara bersama-sama dengan satu variabel dependen."(Sugiyono, 2017)

\section{Regresi Ganda}

"Analisis regresi ganda digunakan oleh peneliti, bila peneliti bermaksud meramalkan bagaimana keadaan (naik turunnya) variabel dependen (kriterium), bila dua atau lebih variabel independen sebagai faktor prediktor dimanipulasi (dinaikturunkan nilainya)."(Sugiyono, 2017)

\section{Koefisien Determinasi}

"Koefisien determinasi dihitung dengan mengkuadratkan koefisien korelasi yang telah ditentukan, dan selanjutnya dikalikan dengan 100\%.”(Sugiyono, 2017)

\section{Uji T (Dua Pihak)}

Uji t digunakan untuk menguji hipotesis untuk mengetahui seberapa besar hubungan atau tingkat signifikansi hubungan antara satu variabel independen terhadap satu variabel dependen. "Uji dua pihak digunakan bila hipotesis nol (Ho) berbunyi "sama dengan" dan hipotesis alternatifnya (Ha) berbunyi "tidak sama dengan" ( $\mathrm{Ha}=; \mathrm{Ha} \neq)$.”(Sugiyono, 2017)

\section{Uji F}

"Uji f menunjukkan apakah semua variabel independen mempunyai pengaruh secara simultan terhadap variabel dependen.”(Ghozali, 2018)

\section{Hasil Dan Pembahasan}

\section{Uji Normalitas}

Uji normalitas perlu dikerjakan untuk melihat apakah distribusi data normal atau tidak, dikarenakan menggunakan data berbentuk rasio, maka memerlukan distribusi data yang normal. Distribusi data dianggap normal jika signifikansi $>0,05$. 
Tabel 3

\section{Hasil Uji Normalitas}

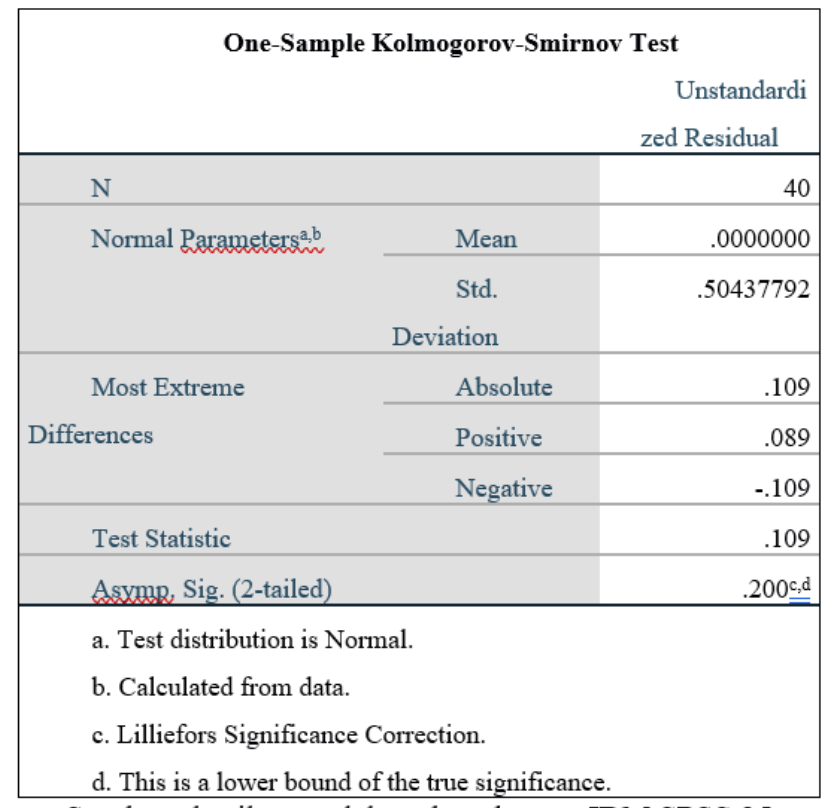

Sumber : hasil pengolahan data dengan IBM SPSS 25

Dilakukan pengujian statistik dengan model Kolmogoorov-Smirnov setelah dilakukan transformasi terhadap data harga saham (Y) sehingga didapatkan hasil asymp. Sig.(2-tailed) sebesar 0,200 dimana 0,200 >0,05 sehingga distribusi data yang didapatkan berbentuk normal sehingga dalam penelitian ini dapat menggunakan statistik parametris. Penelitian ini menggunakan statistik parametris dikarenakan data berebentuk rasio.

\section{Korelasi Product Moment}

Analisis korelasi product moment digunakan untuk menguji hubungan Return On Asset (X1) dan Net Profit Margin (X2) terhadap harga saham (Y) secara parsial. Kriteria yang digunakan dapat dilihat pada tabel 3.3. Setelah dilakukan pengujian menggunakan IBM SPSS didapatkan bahwa :

Tabel 4

Hasil Korelasi Product Moment

\begin{tabular}{|c|c|c|c|c|}
\hline \multicolumn{5}{|c|}{ Correlations } \\
\hline & & ROA & NPM & $\begin{array}{l}\text { HARGA } \\
\text { SAHAM }\end{array}$ \\
\hline \multirow[t]{3}{*}{ ROA } & $\begin{array}{l}\text { Pearson } \\
\text { Correlation }\end{array}$ & 1 & $.942^{* *}$ & .225 \\
\hline & Sig. (2-tailed) & & .000 & .162 \\
\hline & $\mathrm{N}$ & 40 & 40 & 40 \\
\hline \multirow[t]{3}{*}{ NPM } & $\begin{array}{l}\text { Pearson } \\
\text { Correlation }\end{array}$ & $.942^{* *}$ & 1 & .237 \\
\hline & Sig. (2-tailed) & .000 & & .141 \\
\hline & $\mathrm{N}$ & 40 & 40 & 40 \\
\hline \multirow[t]{3}{*}{ HARGA SAHAM } & $\begin{array}{l}\text { Pearson } \\
\text { Correlation }\end{array}$ & .225 & .237 & 1 \\
\hline & Sig. (2-tailed) & .162 & .141 & \\
\hline & $\mathrm{N}$ & 40 & 40 & 40 \\
\hline
\end{tabular}

Dari hasil pengujian diatas untuk menentukan kekuatan hubungan dari korelasi product moment dilihat sig.(2-tailed) nya dan di cek intervalnya dapat menggunakan : 


\section{Tabel 5}

Korelasi Product Moment

\begin{tabular}{|c|c|}
\hline Interval Koefisien & Tingkat Hubungan \\
\hline $0,00-0,199$ & Sangat Rendah \\
\hline $0,20-0,399$ & Rendah \\
\hline $0,40-0,599$ & Sedang \\
\hline $0,60-0,799$ & Kuat \\
\hline $0,80-1,000$ & Sangat Kuat \\
\hline
\end{tabular}

Sumber: (Sugiyono,2017:278)

Berdasarkan hasil pengujian menggunakan IBM SPSS dan dilihat dari tabel tingkat hubungan diatas didapatkan bahwa :

1. Dilihat dari nilai Perason Correlation didapatkan bahwa hubungan antara variabel Return On Asset (ROA) (X1) terhadap harga saham (Y) adalah sebesar 0,225 yang berada di interval 0,20 - 0,399 yang menunjukkan bahwa hubungan yang terjadi adalah rendah.

2. Dilihat dari nilai Perason Correlation didpatkan bahwa hubungan antara variabel Net Profit Margin (NPM) (X2) terhadap harga saham (Y) adalah sebesar 0,237 yang berada di interval $0,20-0,399$ yang menunjukkan bahwa hubungan yang terjadi adalah rendah.

\section{Korelasi Ganda}

Analisis korelasi ganda digunakan untuk menguji apakah ada hubungan Return On Asset (X1) dan Net Profit Margin (X2) terhadap harga saham (Y) dalam simultan.

\section{Tabel 6}

Hasil Korelasi Ganda dan Koefisien Determinasi

\begin{tabular}{|c|c|c|c|c|c|c|c|c|c|}
\hline \multicolumn{10}{|c|}{ Model Summary } \\
\hline \multirow[b]{2}{*}{ Model } & \multirow[b]{2}{*}{$\mathrm{R}$} & \multirow[b]{2}{*}{ R Square } & \multirow[b]{2}{*}{$\begin{array}{l}\text { Adjusted R } \\
\text { Square }\end{array}$} & \multirow[b]{2}{*}{$\begin{array}{l}\text { Std. Error of } \\
\text { the Estimate }\end{array}$} & \multicolumn{5}{|c|}{ Change Statistics } \\
\hline & & & & & $\begin{array}{r}\text { R Square } \\
\text { Change }\end{array}$ & F Change & d11 & $\mathrm{d} f 2$ & $\begin{array}{l}\text { Sig. F } \\
\text { Change }\end{array}$ \\
\hline 1 & $237^{a}$ & .056 & .005 & 51783 & .056 & 1.101 & 2 & 37 & .343 \\
\hline
\end{tabular}

Sumber : hasil pengolahan data dengan IBM SPSS 25

Berdasarkan hasil pengujian menggunakan IBM SPSS diatas dan dilihat dari interval dari tabel 4.12. didapatkan bahwa nilai $\mathrm{R}$ didapatkan bahwa hubungan variabel Return On Asset (ROA) (X1) dan Net Profit Margin (NPM) (X2) terhadap harga saham (Y) secara simultan adalah 0,237 yang berada di interval 0,20-0,399 yang menunjukkan bahwa hubungan yang terjadi adalah rendah.

\section{Regresi Ganda}

Analisis korelasi ganda dikerjakan dalam mengetahui seberapa besar pengaruh yang diberikan variabel Return On Asset (X1) dan Net Profit Margin (X2) terhadap variabel harga sama $(\mathrm{Y})$ dengan memanipulasi nilai variabel X1 dan X2. 
Tabel 7

Hasil Regresi Ganda dan Uji T

\begin{tabular}{|c|c|c|c|c|c|}
\hline \multicolumn{6}{|c|}{ Coefficients $^{a}$} \\
\hline & $\begin{array}{l}\text { Unsta } \\
\text { Coeffic }\end{array}$ & dized & $\begin{array}{l}\text { Standardiz } \\
\text { ed Coefficients }\end{array}$ & & \\
\hline Model & $\mathrm{B}$ & Std. Error & Beta & $\mathrm{t}$ & Sig. \\
\hline $\begin{array}{lll} & & \text { (Consta } \\
& \mathrm{nt}) & \end{array}$ & 2.529 & .084 & & $\begin{array}{r}30.09 \\
7\end{array}$ & .000 \\
\hline ROA & .002 & .040 & .019 & .040 & .969 \\
\hline NPM & .002 & .004 & .219 & .462 & .647 \\
\hline
\end{tabular}

Dari tabel diatas didapatkan bahwa

Konstanta a : 2,529

Koefisien $b_{1}: 0,002$

Koefisien $\mathrm{b}_{2}: 0,002$

Sehingga didapatkan persamaaan regresi ganda sebagai berikut :

$\mathrm{Y}=2,529+0,002 \mathrm{X}_{1}+0,002 \mathrm{X}_{2}$

Berdasarkan hasil pengujian menggunakan IBM SPSS diatas didapatkan bahwa :

1. Konstanta a sebesar 2,529 artinya apabila nilai Return On Asset dan Net Profit Margin konstan, maka harga saham sebesar 2,529.

2. Koefisien $b_{1}$ sebesar 0,002 artinya apabila variabel Return On Asset dinaikkan satu kali maka harga saham akan meningkat 0,002 .

3. Koefisien $b_{1}$ sebesar 0,002 artinya apabila variabel Net Profit MArgin dinaikkan satu kali maka harga saham akan meningkat 0,002

\section{Koefisien Determinasi}

Analisis koefisien determinasi digunakan untuk menguji seberapa besar pengaruh yang diberikan variabel Return On Asset (X1) dan Net Profit Margin (X2) terhadap variabel harga sama $(\mathrm{Y})$. Hasil dari koefisien determinasi dapat dilihat pada tabel 6. Berdasarkan dari tabel diatas didapatkan bahwa nilai $\mathrm{R}$ square adalah 0,056 atau 5,6\% yang artinya pengaruh yang diberikan oleh variabel Return On Asset dan Net Profit Margin terhadap harga saham adalah $5,6 \%$ dan $94,4 \%$ lainnya dipengaruhi oleh variabel lain.

\section{Uji T}

Analisis Uji t dilalukan dalam menguji hipotesis untuk mengetahui seberapa besar hubungan atau tingkat signifikansi hubungan antara variabel Return On Asset (X1) dan Net Profit Margin (X2) terhadap variabel harga saham (Y) secara parsial. Hasil analisis dapat dilihat dari tabel 7. Berdasarkan analisis tersebut didapatkan bahwa :

1. Variabel Return On Asset menunjukkan bahwa $\mathrm{t}_{\text {hitung }}<\mathrm{t}_{\text {tabel }}$ yaitu $0,04<2,026$ yang berarti Ho diterima Ha ditolak artinya tidak ada terdapat pengaruh variabel Return On Asset (X1) terhadap variabel harga saham (Y). Kesimpulan ini ditunjukkan dengan kurva sebagai berikut :

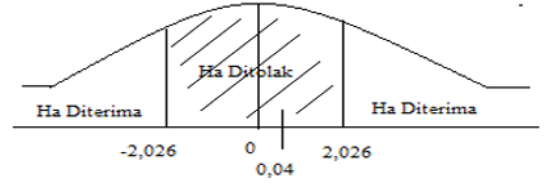

\section{Gambar 3. Kurva Uji T Dua Pihak Return On Asset}

2. Variabel Net Profit Margin menunjukkan bahwa $t_{\text {hitung }}<t_{\text {tabel }}$ yaitu $0,462<2,026$ yang berarti Ho diterima Ha ditolak artinya tidak ada terdapat pengaruh variabel 
Net Profit Margin (X2) terhadap variabel harga saham (Y). Kesimpulan ini ditunjukkan dengan kurva sebagai berikut :

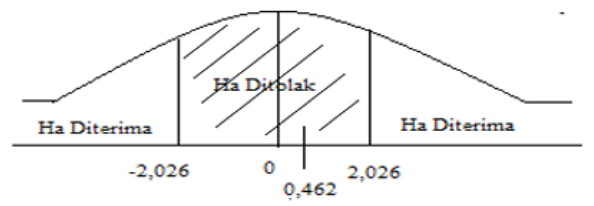

Gambar 4. Kurva Uji T Dua Pihak Net Profit Margin

\section{Uji F}

Analisis Uji f digunakan untuk menguji hipotesis untuk mengetahui seberapa besar hubungan atau tingkat signifikansi hubungan antara variabel Return On Asset (X1) dan Net Profit Margin (X2) terhadap variabel harga saham (Y) secara simultan.

Tabel 8

Hasil Uji F

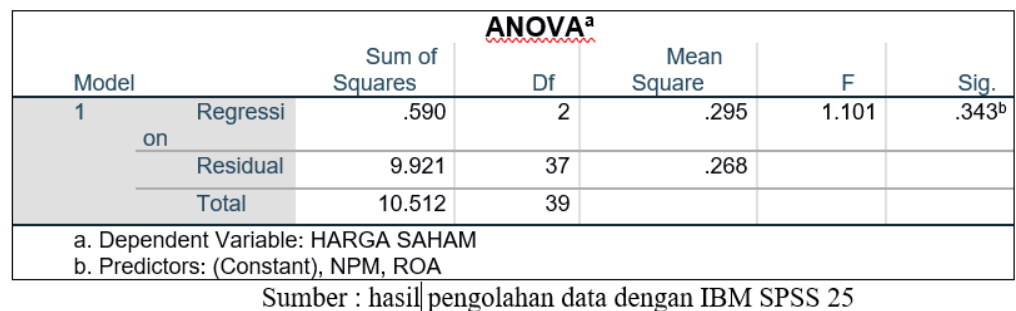

Berdasarkan analisis tersebut didapatkan bahwa nilai $\mathrm{f}_{\text {hitung }}<\mathrm{f}_{\text {tabel }}$ yaitu $1,101<$ 3,25 sehingga Ho diterima dan Ha ditolak yang artinya tidak terdapat pengaruh antara varibel Return On Asset dan Net Porfit Margin terhadap variabel harga saham secara simultan. Kesimpulan ini ditunjukkan dengan kurva sebagai berikut :

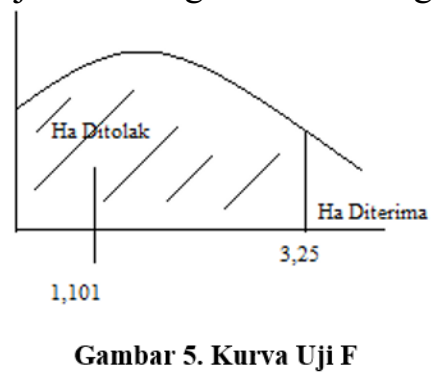

\section{Pembahasan}

Pengaruh Return On Asset Terhadap Harga Saham Perusahaan Pada Sub Sektor Hotel, Restoran, dan Pariwisata yang Tercatat di BEI.

Setelah dilakukannya penelitian dapat diambil kesimpulan bahwa Return On Asset tidak memiliki pengaruh terhadap besarnya harga saham. Maka, harga saham akan konstan walaupun terjadi kenaikan maupun penurunan pada Return On Asset pada perusahaan sub sektor hotel, restoran, dan pariwisata yang tercatat di BEI.

\section{Pengaruh Net Profit Margin Terhadap Harga Saham Perusahaan Pada Sub Sektor Hotel, Restoran, dan Pariwisata yang Tercatat di BEI.}

Setelah dilakukannya penelitian dilakukanlah kesimpulan bahwa Net Profit Margin tidak memiliki pengaruh terhadap besarnya harga saham. Maka, harga saham akan 
konstan walaupun terjadi kenaikan maupun penurunan pada Net Profit Margin pada perusahaan sub sektor hotel, restoran, dan pariwisata yang tercatat di BEI.

\section{Pengaruh Net Profit Margin Terhadap Harga Saham Perusahaan Pada Sub Sektor Hotel, Restoran, dan Pariwisata yang Tercatat di BEI}

Setelah dilakukannya penelitian diambil kesimpulan bahwa Return On Asset dan Net Profit Margin secara simultan tidak memberikan pengaruh terhadap besarnya harga saham. Walau kedua variabel tersebut diubah, besaran harga saham akan konstan atau perubahan yang terjadi tidak terlalu terlihat. Dikarenakan sampel yang terdapat adalah perusahaan sub sektor hotel, restoran, dan pariwisata yang tercatat di BEI, maka kesimpulan ini berlaku pada perusahaan jenis ini saja. Hal ini juga didukung dengan penelitian yang telah ada secara parsial dimana kedua variabel Return On Asset dan Net Profit Margin tidak memberikan pengaruh pada harga saham.

\section{Kesimpulan}

Berdasarkan hasil penelitian yang dilakukan atas pengaruh Return On Asset dan Net Profit Margin terhadap harga saham pada perusahaan sub sektor hotel, restoran, dan pariwisata yang tercatat di BEI periode 2015-2019, maka dapat diambil kesimpulan bahwa :

1. Hasil dari pengujian hipotesis yang telah dilakukan didapatkan Return On Asset tidak memiliki pengaruh terhadap harga saham dari perusahaan sub sektor hotel, restoran, dan pariwisata yang tercatat di BEI periode 2015-2019.

2. Hasil dari pengujian hipotesis yang telah dilakukan didapatkan Net Profit Margin tidak memiliki pengaruh terhadap harga saham dari perusahaan sub sektor hotel, restoran, dan pariwisata yang tercatat di BEI periode 2015-2019.

3. Hasil dari pengujian hipotesis yang telah dilakukan didapatkan Return On Asset dan Net Profit Margin saat diuji secara simultan tidak memiliki pengaruh terhadap harga saham dari perusahaan sub sektor hotel, restoran, dan pariwisata yang tercatat di BEI periode 2015-2019.

\section{Daftar Pustaka}

Egam, G. E. Y., Ilat, V., \& Pangerapan, S. (2017). Pengaruh Return On Asset (ROA), Return On Equity (ROE), Net Profit Margin (NPM), Dan Earning Per Share (EPS) Terhadap Harga Saham Perusahaan Yang Tergabung Dalam Indeks LQ45 Di Bursa Efek Indonesia Periode Tahun 2013-2015. EMBA, 5(1), 105-114. https://doi.org/10.1007/978-1-349-15400-5_6

Ghozali, I. (2018). Aplikasi Analisis Multivariate Dengan Program IBM SPSS 25 (9th ed.). UNDIP.

Nurhayat, W. (2018). BPS: Tren Okupansi Hotel Bintang 5 di RI Selama Mei Turun. https://kumparan.com/kumparanbisnis/bps-tren-okupansi-hotel-bintang-5-di-riselama-mei-turun-27431110790536743/full

Samosir, H., Simorangkir, E. N., Stephanus, A., Ginting, K. E. M., Banjarnahor, Y. S., \& Br Sitepu, M. P. (2019). Pengaruh Current Ratio (CR), Net Profit Margin (NPM), dan Kebijakan Dividen terhadap Harga Saham pada Perusahaan Consumer Goods Yang Terdaftar Di Bursa Efek Indonesia (BEI) Pada Periode 2013-2017. Owner, 3(2), 15. https://doi.org/10.33395/owner.v3i2.117

Saputra, I., Veny, V., \& Mayangsari, S. (2019). Pengaruh Rasio Keuangan, Aksi Korporasi Dan Faktor Fundamental Ekonomi Makro Terhadap Harga Saham. Jurnal Magister Akuntansi Trisakti, 5(1), 89. https://doi.org/10.25105/jmat.v5i1.5078

Sugiyono. (2017). Metode Penelitian Bisnis (S. Y. Suryandari (ed.); 3rd ed.). Alfabeta.

Ulfah, E., Andini, R., \& Oemar, A. (2018). Pengaruh CR, DER, ROA Dan Ukuran Perusahaan Terhadap Harga Saham Dengan Kebijakan Dividen Sebagai Variabel 
Intervening. 74(4), 55-61.

Zulkifli Hasibuan, M. (2018). Analisis Pengaruh Rasio Keuangan Terhadap Return Saham Dengan Tingkat Inflasi Perubahan Kurs Dan Tingkat Suku Bunga Sebagai Variabel Moderating ( Empiris Pada Perusahaan Manufaktur Yang Terdaftar Di Bursa Efek Indonesia). Jurnal Bisnis Administrasi, 07, 1-08. 